\title{
A Pragmatic Analysis of Labor Standards in Compliance with ILO and Islam: Bangladesh Perspective
}

\author{
Md. Hasnath Kabir Fahim \\ Lecturer, School of Law, Chittagong Independent University, Chittagong, Bangladesh \\ Email: fahim.law22@gmail.com
}

How to cite this paper: Fahim, Md. H. K. (2020). A Pragmatic Analysis of Labor Standards in Compliance with ILO and Islam: Bangladesh Perspective. Beijing Law Review, 11, 544-560. https://doi.org/10.4236/blr.2020.112033

Received: April 20, 2020

Accepted: May 25, 2020

Published: May 28, 2020

Copyright $\odot 2020$ by author(s) and Scientific Research Publishing Inc. This work is licensed under the Creative Commons Attribution International License (CC BY 4.0).

http://creativecommons.org/licenses/by/4.0/

\section{(c) (i) Open Access}

\begin{abstract}
In this era of industrialization, laborers are said to be the key factor of industrial development of any country as the national economic stability directly or indirectly depends upon the standards of labor practice. The credence of labor rights bears staple importance where the International Labor Organization (ILO) acknowledges manifold rights and principles as the core international labor standards. Bangladesh, a Muslim majority country has promulgated the Bangladesh Labor Act in 2006 to accomplish its national obligation as a member of ILO. To this context, this research is an attempt to investigate the extent of compliance of Bangladesh labor laws and practices with the labor standards of ILO and Islamic principles of labor rights. This paper additionally tries to highlight the root causes of poor implementation mechanism and defects of labor law in Bangladesh. Finally certain recommendations are suggested for the fruitful and efficient implementation of labor standards to ensure rights and social justice to workers of every corner of the country and safeguard the national economy from innumerable loss.
\end{abstract}

\section{Keywords}

Bangladesh Labor Act, ILO, Industries, Labor Rights, Core International Labor Standards

\section{Introduction}

The emergence of international standard for the protection of laborers is one of the remarkable developments of international law and apart from this, Islam as a religion plays a significant role in the promotion of labor rights as one of its major principles. Numerous labor rights are enshrined from these two streams and 
promoted to codify several international labor and human rights instruments. Labor rights are usually diverse entitlements relating to the role of being a laborer and these rights are exercised both individually and collectively. It is noted that many general human rights are simply relevant with labor rights concept as they relate to the exigent precondition to assure labor rights such as right to life, right to be protected from arbitrary and unfair dismissal, right to personal liberty, protection of privacy, freedom from torture and freedom of expression etc. (Elbert \& Oelz, 2012). The International Labor Organization (ILO) has framed a set of minimum best labor practices to safeguard the interest of the workers worldwide. Freedom of association, right to form trade union and collective bargaining agent, protection against forced labor, abolition of child labor and safeguard against any sort of discrimination at workplace, right to equal remuneration are some of the citable rights acknowledged by the elemental eight conventions of ILO as the core international labor standards. These labor standards focus on certain challenges that laborers face in employment and ways to make labor rights more static and precise. Manifold international human rights instruments like Universal Declaration of Human Rights (UDHR), UN Convention on the Rights of the Child and Copenhagen Declaration on Social Development somehow recognize these labor rights as international code of labor standards (Chowdhury, 2017). The UDHR in its article 4, 23 and 24 forbids slavery, ensures right to work in a job chosen freely, right to decent wages, right to form trade union and right to leisure and limitations of working hours respectively. Additionally the European Union Charter of Fundamental Rights (EUCFR) comprises multiple labor rights such as right to information and consultation, safeguard from unjust dismissal and prohibition of forced labor. However, the ILO was founded in 1919 and predates all human rights instruments and organizations and it is clear that the labor issues turned into an affair of international concern prior to the human rights (Mantouvalou, 2012). Thus the core international labor standards are reflected in domestic level when any country ratifies the relevant ILO conventions or if the constitution or any other legislation of that country bestows numerous labor rights for the workers. ILO encourages the member states to facilitate and adopt initiatives for standardizing international labor standards within their national jurisdiction and according to the directions of the Declaration on Fundamental Principles and Rights at Work (1998) as well as the Philadelphia Declaration (1944) the member states are bound to promote and comport with the ILO's eight core conventions without envisaging their ratification of those conventions. Thus, it is an indication towards all ILO members to enhance and comply with the core international labor standards and beside ILO the Asian Development Bank considers core international labor standards as indispensable for national economic progression and to safeguard human rights of the workers. Unfortunately many countries around the world always treated the core international labor standards as adverse to the business policy (Chowdhury, 2017). Countries framing development goal without complying with the core international labor standards and considering labor rights 
as secondary objective, can hardly attain their fraught economic success.

Islam being a divine law bears unique feature of labor standards and redact a momentous role to protect and ameliorate labor rights. Allah (SWT) says that the laborer should be treated with dignity, kindness and humanly as there is no room for exploitation in Islam against laborer. Oppression against worker is strictly prohibited and the laborer who earns fairly is honored in Islam. In dealings of trade between the employer and worker, maintaining social justice is obligatory as Islam secures the rights of the weak party against unfair advantage. Woman employment is verily encouraged in Islam and no discrimination can be made based on gender, race and color at workplace. In the early Islamic era, women were remarkably engaged in public administration and many industries, labor markets were entirely dominated by women traders (Arshadul, 2018). Islam has scheduled working hour limit, working place safety, hygiene policy and orders not to overburden the workers. It is mentioned in a Hadith that "It is the duty of the employers to give only such work for their employees that they can easily do". Islam has strict regulations relating to wages of laborer and without prior fixation of remuneration it is forbidden to hire a laborer. The Prophet Muhammad (PBUH) said "Give the wages to worker before the sweat is dry on him". It is an Islamic obligation upon the employer to provide laborers sufficient wages that cover all basic necessities like good food, clothing, housing, medical allowance and other facilities in conformity with prevailing social and economic condition (Arshadul, 2018). Undue delay in payment of wages is a great sin in Islam and Allah said "I never cause loss to a worker, be that male or female". Various verses from Hadith conclude about profit sharing with the workers and Zakat system of Islam is the way to maintain social equity and share profit with poor (Zulfiqar, 2007). Zakat is collected from wealthy and then contributed to the welfare of the needy. This is how Islam guides to maintain social harmony and labor standards free from discrimination and exploitation.

The parliament of Bangladesh has introduced the core international labor standards in national labor laws but the protection and enforcement mechanisms still suffer assorted loopholes. Number of legislations are there that are in compliance with core international labor standards such as the Constitution of Bangladesh, the Labor Act, 2006, the Labor Rules, 2015, the EPZ Workers Welfare Association and Industrial Relations Act, 2010, Bangladesh Export Processing Zone Authority (BEPZA) Act, 1980, BEPZA Instruction No 1 \& 2 of 1989, the National Labor Policy 2012, National Child Labor Policy 2010 where the Labor Act, 2006 is the primary legislation to regulate labor standards in Bangladesh. However these regulations provide both substantive and procedural measures to assure labor rights. Thus the Labor Act, 2006 is the comprehensive law that covers the core international labor standards and norms regarding employment condition, working hours and leave, industrial relations and trade union activities, minimum rate of remuneration, occupational safety and health issues, maternity benefit, industrial violence settlement mechanism, labor administration and many more (Islam \& Rahman, 2015). Bangladesh has already rati- 
fied seven ILO conventions and the national labor law system is erected on the theory of social justice which also frames the corner stone of ILO's labor norms (Hossain, 2013). As Bangladesh is a Muslim majority country, the norms of Islam have deep influence on both ruler and the ruled (Arshadul, 2018). The Constitution of Bangladesh in its Article 2A establishes Islam as state religion. Islamic canons may have prominent impact in labor laws of many Muslim countries but the labor policy of Bangladesh does not entirely comply with the Islamic provisions of labor standards. Furthermore, the labor laws of Bangladesh may have the essence of Islamic labor law in some extents that may not be in compliance with core international labor standards. But all these provisions can create more convenient approach for enhancing the labor standards of Bangladesh.

\section{An Overview of Labor Standards in Bangladesh Labor Act}

Labor law craves to wield the relationship between the employers and their labor forces as well as governs the policies of state through which the cohesion between the employer and worker is regulated to withhold peace in the industrial sector. The history of labor law is about century old in Bangladesh and the first enactment on labor regulation of this Indian sub-continent was the Indian Factories Act which made in 1881 (Dhar, 2011). In 1947 after the separation of Indian sub-continent, most of the enactments of British period were adopted by Pakistan and after the emergence of Bangladesh in 1971 the previous laws were retained by the government of Bangladesh. Since 22 June, 1972 Bangladesh has been an active member of ILO and as many as 50 laws were there to regulate labor issues in the country. To expedite the labor law and enact a patulous legislation in compliance with core international labor standards, the National Labor Law Commission was formed in 1992 with representatives from workers, employers, Government representatives and legal experts (Paul, 2014). The Commission interviewed different stakeholders of labor regulation as well as examined 44 labor laws and submitted its report on 31 March, 1994. It was recommendation of the Commission to repeal 27 laws as well as it prepared a draft of Labor Act and after a long successful discussion with the employers and workers, on 11 October, 2006 the Bangladesh Labor Act was passed repealing 25 existing laws of the country (Hossain, Ahmed, \& Akter, 2010). This Labor Act, 2006 is the core legislation to administer labor regulation in Bangladesh. However, still 25 laws on labor issues are there in Bangladesh neither repealed nor consolidated and the Labor Act has not factually consolidated all the laws on labor regulation (Halim, 2019).

The Labor Act of Bangladesh principally governs the regulations for workers employed in non-government establishment in Bangladesh. It is only the laborer who is the core determining factor for jurisdiction and application of the Act. The Act has been regarded as a modern legislation as it removes certain ambiguities of earlier labor laws and imbibed the principles of ILO Conventions (Hossain, 2013). The new Labor Act bears some notable changes like issuing of iden- 
tity cards, encouraging woman workers in trade union, youth labor and non-transfer of trade union officers etc. (Chowdhury \& Rahel, 2018). The law additionally deals with labor employment, industrial relations between worker and employer, determination and payment of wages and compensation, provident fund, formation of trade union and collective bargaining agent, working hours and leave, maternity benefit, raising and settlement mechanism of industrial dispute, labor court and appellate tribunal, penalty and procedure, administration and inspection, health and workplace safety issue and other related matters (Sharma, 2015). Moreover, the Labor Act has also guidelines regarding manufacturing, newspaper workers, tea-garden workers, marine and ship-building workers. Thus the ultimate goal of the Act is to sustain harmonious relationship between employer and laborer, security of employment and rapid growth of production of business establishments which can enhance the economic development of Bangladesh (Islam, 2015). For smooth implementation of the Labor Act, 2006, the government of Bangladesh has also introduced the Labor Rules, 2015. The Labor Act has gone through several amendments which were made in 2008, 2009, 2010, 2013 and 2018. Among the eight ILO conventions Bangladesh has ratified seven conventions except the ILO convention on minimum age of the workers. From these provisions of the Bangladesh Labor Act, 2006 it can be realized that the Labor Act fairly meets the core international labor standards of ILO and Islamic norms of labor rights.

\section{Compliance Limit of Bangladesh Labor Act with ILO and Islam}

Bangladesh is a developing country striving hard to attain industrial durability by eradicating poverty and no doubt the labor sector is significantly the integral part thereto (Sharma, 2015). Complying with the core international labor standards Bangladesh has promulgated the Labor Act, 2006 but the feasible application of the labor regulations is still cloud castle. Although 25 previous labor laws are consolidated by the Bangladesh Labor Act, 2006 but still there remains other relevant labor laws in Bangladesh and such multiplicity of legislations can create barrier to fruitful observance of core international labor standards. Among the eight ILO conventions Bangladesh has not yet ratified the convention on minimum age of the laborer. Thus widespread infringement of labor laws and labor rights are there in every labor sector of Bangladesh. Defective enforcement mechanism and prevarication of labor rights is the gateway for disgracing core international labor standards in Bangladesh (Chowdhury, 2017). Negligence of employers, complex regulations and judicial perplexities have added more agony in the fate of laborers. In all private sectors, employers hire workers in short-term basis which brings serious injustice to the workers and hardship such as low remuneration, underpayment, lengthy working hour, unsecured employment system, gender discrimination, hazardous working condition, nominal social benefits and weaker legal remedy are common risks in private establishments of the country (Sharma, 2015). The associations of workers like trade unions may not 
operate property leaving them unorganized and they cannot raise their voice even in case of plentiful observance of health and safety measures in workplace (Chowdhury \& Rahel, 2018). Many incidents of laborer injuries took place in industries like ship breaking, garments, steel mills and construction sites while very few of them are compensated. Unfortunately there is no noteworthy precedent to ensure accountability of such unfair labor practice in Bangladesh.

\subsection{Narrow Application of Labor Law}

The Bangladesh Labor Act, 2006 is not applicable for the informal working sectors and thus these laborers are deprived of their elemental labor rights. The Act is applicable for the workers engaged in industries, factories and other business establishments but not to every establishment where laborers are working because Section 1 (4) of the Act declares that Bangladesh Labor Act is applicable only to formal private sector within Bangladesh. As the workers from informal sector are beyond the shadow of the Labor Act, there are no statutory rules of dispute settlement mechanism for them and no systematic policy available for determining the terms and conditions of their service. Importantly the Labor Act does not apply to many informal workers such as domestic workers, agricultural workers and individuals doing managerial functions though these informal workers compose a large portion of labor sector in Bangladesh. Most of the rights and benefits enumerated in Labor Act are not available for them and absence of solid demand for legal protection from these poorly organized workers is the core reason for the resistance of informal sector (Chowdhury, 2017). These ill-fated informal sector workers do not enjoy the nominal measure of support and aid from the state and remain helpless as well as neglected throughout their service.

The core subject matter of the Bangladesh Labor Act, 2006 is "worker" and the status of an employee does not fall within the definition of "worker" leaving him/her outside the purview of the Act. Labor Act defines worker as a person appointed in any commercial establishment engaged in doing skilled, unskilled, manual, technical, trade promotional or clerical job for hire or reward. But any person appointed to perform managerial or administrative functions are not considered as worker and differentiation merely on the point of their designation is not a discreet ground (Chowdhury, 2017). As these employees doing managerial and administrative works in an establishment do not fall within the scope of Labor Act so they can not join trade union of workers.

\subsection{Exploitation on Temporary Workers}

The Bangladesh Labor Act in its Section 4 categorized workers giving the employers of private sector another opportunity of exploitation. In Bangladesh most of the laborers are employed on temporary basis and these temporary workers receive their daily wages for works of ad-hoc or casual in nature (Sharma, 2015). Subsequently they are always treated as unskilled and irregular workers and never get the status of permanent worker due to their casual or ad-hoc 
nature of work. Thus benefits, additional wages and other compensations which are laid down in Labor Act are never enjoyed by this large portion of workers and unfortunately the labor laws are operating for only a very small portion of workers who are entitled to the core international labor standards in Bangladesh. To escape from providing the benefits of permanent employment, the employers of private sector commonly employ temporary workers creating another hindrance towards unionism of workers (Sharma, 2015). Later on, the temporary workers are not generally promoted as permanent workers showing numerous excuses and employers consistently deprive them and as a result very limited number of workers gets lasting employment experience spanning between 3 to 10 years (Chowdhury, 2017).

\subsection{Imbalanced Industrial Relation}

Lack of regular employment system, absence of favorable employer-employee relationship and non-observance of proper labor standards are common factors in informal business sectors of Bangladesh. Informal job sectors like agriculture, construction, household work, security job, medical clinics, groceries and service under subcontractor are widespread in the country and laborers of these informal sectors do not enjoy minimum working limit to be eligible for statutory benefits. High rate of vulnerability exists for informal laborers as they are employed on seasonal, casual or contractual basis. Furthermore, as the Labor Act is not applicable for these laborers, they remain unrecognized and not entitled to employment facilities including social safeguard as laborer. Unfortunately a laborer employed in informal sector gets payment only for those days he/she works and if he/she remains absent on a particular day receives no wages for that day which compels them to live in bitter poverty (Chowdhury, 2017). Compensation rate for these workers is very low compared to permanent workers and very often it is found that the working conditions for informal workers are unsafe and hazardous (Sharma, 2015). The compensation rate is even discriminatory for working injury between adolescent and adult laborers. The laborers of Bangladesh are generally from poor class of people and job security is a matter of concern for their livelihood (Hossain, Ahmed, \& Akter, 2010). Temporary workers of informal sector do not often receive appointment letter and identity card to prove their legal rights as laborer (Hossain, 2013). Employers enjoy arbitrary power to cease any worker without giving any compensation and factually there is no protection on wages for laborers employed in informal sectors of Bangladesh. Such discrimination of informal workers is against the spirit of the ILO convention concerning discrimination at work.

\subsection{Ambiguous Definitions of Worker}

The term "worker" has got multiple definitions in different labor legislations of Bangladesh. For instance, the Labor Act, 2006, the EPZ Workers' Welfare Association and Industrial Relations Act, 2010, the Labor Welfare Foundation Act, 2006, State-owned Manufacturing Industries Workers (Conditions of Service) 
Act, 1993 define the terms "worker", “employer", "establishment", "wages" in varied ways and these statutes has made erosion towards proper implementation of labor laws in the country. Ambiguity and lack of uniformity of independent labor statutes have disturbed the fertile application of core international labor standards in Bangladesh. Moreover, these statutes provide for individual set of administrative and adjudicatory bodies to regulate various labor issues such as industrial relations, collective bargaining, trade union actions and settlement of disputes etc. This creates agitation in the application of core international labor standards and instigates discrimination among laborers (Chowdhury, 2017).

\subsection{Restriction on EPZ Workers}

In Bangladesh, the application of common labor standards is restricted in export zones like many other countries of the world. Export Processing Zones (EPZ) are established in the country under the Bangladesh Export Processing Zones Authority (BEPZA) Act, 1980. To maintain minimum labor standards in these zones, BEPZA Instructions I \& II were additionally introduced but miscellaneous restrictions are imposed on the rights of EPZ workers by these instructions. For example, permitting of leave is upon the mercy of the factory manager and laborers cannot claim leaves as of their right and benefits like maternity leave, gratuity or compensation are absent there (Chowdhury, 2017). Lack of legal protection of the laborers against health safety hazards is a serious issue in EPZ and the rate of wages of these workers is very inconsistent though the Instructions guarantee minimum rate of remuneration. As per the mandate of the EPZ Workers Welfare Association and Industrial Relations Act, 2010 only one trade union can be formed in any EPZ establishment which would also perform the functions of collective bargaining agent but with cumbersome provisions of implementation (Vogt, 2017). These EPZ workers even after having the status of "worker" under the labor regulations of Bangladesh are deprived of numerous rights guaranteed by the Labor Act which is discriminatory treatment towards them. These provisions are undoubtedly against the guidelines of the ILO Convention 87 (Hossain, 2013).

\subsection{Complexities in Legal Proceedings}

Under the Labor Act, 2006 all labor disputes will be adjudicated by the Labor Court constituted under the Act. However, due to technical loopholes in labor law, defects in dispute settlement process and impact of external issues the labor court's justice system cannot observe the core international labor standards in Bangladesh (Chowdhury, 2017). It is very cumbersome for the laborers and their trade unions to get remedy from labor court at affordable cost as dispute settlement mechanism in labor court is time consuming, expensive and complicated. The Act even does not mention how a worker can be represented by trade union before labor court to claim his/her rights. According to the Labor Act, the labor court within 60 days shall dispose a case but the consequence if the case is not settled within 60 days is not clear in the provision of Act. If the Director of Labor 
rejects the registration application of trade union then appeal can be lodged to the labor court within 30 days but this time limit is comparatively short for worker unions whose members spend long hours daily in working. There is backlog of cases in labor courts of Bangladesh and there is scarcity of labor court as well as number of judges to handle huge number of labor litigations pending (Ahmed \& Parvin, 2015). Thus scarcity of judges, absence of representatives of employer and worker, intentional delay of parties, lengthy process of issuing summons and other complex court proceedings are the root causes of disastrous backlog of cases in labor courts (Chowdhury \& Rahel, 2018). Besides, the reasons of rejection of application for trade union registration are often fabricated and these public officers are always under coercion of the establishment owners (Vogt, 2017). These factors are violating the provisions of the Bangladesh Labor Act and making the implementation of core international labor standards fall away. This is how the ILO conventions are ignored while settling labor violence in Bangladesh.

\subsection{Wages Discrimination and Torture}

According to the Bangladesh Labor Act, both male and female laborers shall be entitled to equal remuneration for same nature of work and this provision complies with the ILO Convention 100 concerning equal remuneration of men and women workers for work of equal value. Bangladesh ratified this ILO convention on 28 January, 1998 and thus female laborers are not usually discriminated regarding wages but in terms of job allocation, increment and promotion they face serious discrimination (Hossain, 2013). Moreover, in garment industries more female laborers are employed than male laborers due to rapid growth of female laborers and they are paid with lower wages compared to male (Sharma, 2015). Sometimes the working conditions of many establishments are badly detrimental for the health of woman workers. The Labor Act specifies minimum six months of service in order to enjoy maternity benefit within the establishment and thus deceiving temporary female workers (Islam, 2015). Laborers working in many apparel industries often do not know whether the minimum remuneration is executed at their workplace. Fortunately the problem is now over after the initiating the Labor Rules 2015. In private establishments workers remain ignorant about overtime working rate and get wages below the legal limit. The Labor Act is silent about the basis of any deduction in wages and it is ambiguous about deduction of wages for unauthorized leave if any casual leave remains due. The review span of the Wages Board to determine minimum wage rate is after every 5 years which flops to cover monthly changes in the expenditure of living for laborers (Sharma, 2015). Moreover, the selection process of representatives as Wages Board members and one independent member is not specified in the Act.

Harassment at workplace is a noteworthy curse for the labor sector of Bangladesh. Mental and physical harassment, abusive language and sexual harassment are common in both formal and informal labor sectors (Chowdhury, 2017). Around $40 \%$ of the garments workers and $30 \%$ of the construction work- 
ers face mental torture and $8.4 \%$ of the construction workers face physical harassment while few workers alleged that they were sexually harassed (Chowdhury, 2017).

\subsection{Unrecognized Leaves}

Various types of leaves are recognized by the Labor Act but all classes of laborers are not entitled to enjoy these leaves especially the tea-garden laborers cannot enjoy casual leave (Sharma, 2015). Regarding the sick leave, the Act bears no provision on leave and remuneration if the illness sustains for a long term. The provisions relating leave in case of abortion, pre-mature delivery and other pregnancy issues are not covered by the Labor Act. Moreover, the provisions on medical and life insurance for the workers are also absent (Thakur, 2017). Such restriction and discrimination are against the core international labor standards noted in ILO Conventions 100 and 111.

\subsection{Absence of Job Security}

It is a mandatory provision of Bangladesh Labor Act to provide appointment letters and identity cards to the laborers but unfortunately most of them are deprived from receiving these vital legal documents (Sharma, 2015). Informal workers do not get these documents and can never claim their labor rights as their employment is based on oral contract. Greedy employers use this opportunity and dismiss laborers without paying any compensation and giving prior notice (Hossain, 2013). However the entire process of termination of employment of worker under the Labor Act is quite easy and exploitative in nature as the Act permits the employer to dismiss a laborer without showing any reason in some situations and these helpless laborers only receive a certain amount of compensation after retrenchment, discharge or dismissal (Sharma, 2015). In case of certain grounds like misconduct, the employer can dismiss the worker without giving any notice and subsequently the worker is deprived of chance for self-defence. Both the rights of the worker to be heard and to compensation are equally violated by such dismissal. This provision is entirely against the due process of law. Moreover, the notice period to dismiss temporary laborers in this regard is also very short (Hossain, Ahmed, \& Akter, 2010). Receiving the compensation after termination of employment is another burden for the dismissed worker because of some bureaucratic formalities. To be entitled for retrenchment and discharge benefit, a laborer shall have minimum one year service experience in the concerned establishment (Sharma, 2015). By practice it is now a weapon for the employers to threaten laborers for their engagement with trade unions or for any sort of conflicts (Hossain, 2013). Furthermore, the Act has categorized laborers into different classes which is thoroughly misused by the employers as in most of the establishments, temporary laborers are hired to avoid payment of diverse workers benefit and evade unionism. These workers are always frightened with "Hire and Fire" practice of the employers. 


\subsection{Interruption on Trade Association Activities}

In Bangladesh due to barriers on trade unions in forming, recognition, conflict settlement and strike, precise functioning of trade unions is exceedingly frigid. As a result factually organized and strong trade union practices are absent in industrial sectors and moreover, in ready-made garments the employers form fake trade union with biased people giving eye-wash to the government (Chowdhury, 2017). Many workers are terminated from employment because of their trade union activities and due to scarcity and vulnerability of job opportunities, these workers are forced not to raise their claims (Hossain, Ahmed, \& Akter, 2010). The Labor Act specifies that trade union leaders should be selected from the concerned establishment which deprives the workers to choose their leaders freely. Laborers in Bangladesh have to work for very lengthy period of time in establishment and hardly get time for trade union activities and this problem is quite acute in garments and ship-breaking industries. Torture in the establishment is the common means to compel the poor laborers to sign on blank document which is corruptly fabricated by the employers in some later circumstances as per their sweet will to deprive any laborer from his/her reasonable benefits (Chowdhury, 2017). Some employers even hire gangsters to oppress workers of their establishments and maintain their dominance over them. Many of the factory owners become members of parliament of the country and as a result the government labor regulations are always in favor of them giving a way to escape legal actions for their unfair labor practices (Rubya, 2015).

The Labor Act requires membership of $20 \%$ of the workers to form trade union though it was $30 \%$ before the amendment of 2018 . Though the limit has been curtailed but still fails to comply with ILO Convention 87 which ensures the right of every worker to form and join trade associations (Hossain, 2013). Again to be the Collective Bargaining Agent (CBA) a trade union must attain membership of one-third of its laborers or achieve minimum $30 \%$ votes of total laborers in the establishment. For the reason of maintaining such huge portion of membership to take the position of CBA is another means to limit trade union rights (Sharma, 2015). Undoubtedly defective and unorganized trade union practice is one of the key causes of labor unrest in Bangladesh as without effective trade union the laborers have no other platform to raise their claims. Intentional negligence of the employers, formation of fake unions, political chaos, lack of dedicated organizers, job scarcity, unawareness and poverty of general laborers are considered as the reasons for deterioration of systematic trade union practice in Bangladesh (Chowdhury, 2017). Some of the corrupt worker leaders have made the situation more grievous. Employers rarely face any sanction of law for their unlawful labor practices and very nominal if any.

Industrial disputes rising at industries are now mostly settled through informal discussion mainly with the HR sections of the establishments and legal provisions of collective bargaining process do not come to light as mentioned under the Bangladesh Labor Act. This is a common scenario of garments industries 
where grievances of laborers are usually mitigated by informal intermediaries (Chowdhury \& Rahel, 2018). Thus the victim workers are consistently deprived of their legal remedy which is another barrier towards implementation of core international labor standards in labor regulation of Bangladesh. The directions of Act are also not clear about the authority of trade union to represent any of its members before the labor court.

\subsection{Barriers of Right to Strike}

Right to strike at establishment is a right of the laborers but many of them are unaware of this right (Hossain, Ahmed, \& Akter, 2010). Moreover, many laborers are even punished for participating in strikes. During industrial violence when workers try to strike to establish their lawful claims, they have to face legal requirements for a legal strike that is very rigid and arduous (Rubya, 2015). The Labor Act bans strikes for first 3 years in new establishments as well as joint-venture industries having foreign partners. Thus laborers of such establishments have no legal remedy if the employer declares lock-out to crack down the trade unions of the laborers and these provisions of the Bangladesh Labor Act badly collide with the core international labor standards (Hossain, 2013).

\subsection{Arbitrary and Forced Labor}

Bangladesh ratified the ILO Conventions 29 and 105 regarding prohibition and abolition of forced or compulsory labor which has two core ingredients namely the work is done under the threat of a penalty and is undertaken involuntarily (Hossain, 2015). The Labor Act determines the working hour of a laborer for eight hours and to a maximum of 10 hours in a day on overtime payment. To employ any laborer beyond his working work, the employer must take the voluntary consent of the concerned laborer and must be informed at least two hours before starting the overtime work. Forced labor is prohibited under the labor regulation of Bangladesh but many employers hardly comply with this rule (Sarker \& Suvo, 2018). Most of the laborers work extra five hours as daily overtime and such illustrations of overtime work shows that the labor regulations of the country fail to comply with the core international labor standards. Sometimes overtime work involves working in dirty and hazardous condition which may cause more severe health injury to the workers. Rules regarding the estimation of overtime wage rate for piece-rated worker are obscure in the Labor Act. The Labor Act does not mention specific weight limit to be carried by workers according to age and physical condition. According to the terms of the Labor Act any female worker should not be forced to work between $10 \mathrm{pm}$ to $6 \mathrm{am}$ without her consent but there is relaxation of this prohibition if the woman worker consents to work between that duration (Hossain, 2013). Unfortunately the Labor Act fails to describe penal sanction against forced labor although it is prohibited under the same Act. Emergency evacuation measures are rarely implemented and deficiencies of fire alarms, firefighting equipments, emergency 
exits as well as nonelectrical emergency lights are seldom common in many factories (Rubya, 2015). The Act states for adequate number of latrines and urinals but fails to mention what qualities as an adequate number. The law is also mute on ratio of alternative exit or other measures against number of workers in case of fire or other disasters.

\subsection{Practice of Child Labor}

Child labor is still a reality in the country though Bangladesh ratified the ILO Convention 182 on prohibition and elimination of child labor. The practice of child labor commonly exists in labor sectors like iron welding, transport sector, poultry farming, construction, manufacturing, fish drying, aluminum factories and vehicle repairing etc. which usually expose harmful chemicals. Children serving as domestic laborers often face untold exploitations including constant shouting, insult and sexual abuse. Any person who is yet to complete age of 14 years is treated as child under the Labor Act, 2006 and the National Child Labor Survey (2002-2003) and UNICEF defines child labor as any work that is beyond the minimum hours depending upon the age of a child and type of the service (Chowdhury, 2017). Thus such child labor is immensely injurious for the mental and physical growth of any children but child labor is widely conventional in Bangladesh due to economic realities (Aktar \& Abdullah, 2013). Many poor families survive on the earning of their children and griping employers take this as advantage as child laborers are cheaper and more obedient than adult laborers. Child laborers are usually employed under oral contract and same nature of works like adult laborers are performed by those children. The most vulnerable group in labor sectors due to non compliance of the core international labor standards is the child workers (Hossain, 2013). The children who are supposed to study and play are now forced to work as well as common risk that child laborers face are exposures to chemical dust, poisonous fumes and intolerable noise etc.

\subsection{Lack of Proper Inspection Mechanism}

The government inspection system over the entire labor sector is burdened with wicked complexities such as deficiency of adequate Inspectors, short resources, inoperative inspection system, non-cooperation of establishment owners, unorganized trade union activities and lack of vigilance of general laborers etc. (Chowdhury, 2017). Inspectors fail to keep proper surveillance over industries and establishments within their local jurisdiction and generally carry inspection only after the occurrence of any incident (Sharma, 2015). Complaints submitted by the labor associations to the Inspectors remain unsettled for months and wicked employers with their strong financial ability can influence the report of Inspectors. The Department of Inspection for Factories and Establishments (DIFE) with a very small size of manpower has got no way out to monitor around eighty million business establishments of the country (Vogt, 2017). They 
do not have any legal authority to force the factory owners to retreat the risks of any workplace and are rarely informed by the employers about the workplace accidents and hazards. Some of the instances of reporting on workplace accidents are seen only in case of few organized establishments. Thus the overall regulation of labor inspection in Bangladesh is poorly in compliance with the ILO Convention 81 on labor inspection. From the above discussion it is quite clear that though the Bangladesh Labor Act, 2006 has adopted the core international labor standards and complies with the norms of Islam but due to feasible approach of implementation, the concept of labor rights and regulation is incompetent to redress the sufferings of the entire labor sector of Bangladesh.

\section{Recommendations}

The Bangladesh Labor Act, 2006 shall be updated with significant provisions of employment rules, health safety and social protection of the workers at large. It is an urgent demand to strengthen labor rights and enforce labor regulations to ensure the core international labor standards irrespective of every labor sector in the country. To establish well-functioning labor standards in Bangladesh, the following recommendations are provided:

- The applicability of the Bangladesh Labor Act shall be expanded to cover laborers of every working sector including domestic, agricultural and informal laborers.

- The minimum requirement of membership of $20 \%$ workers to form trade union shall be abolished to strengthen trade unionism and collective bargaining in the context of workers.

- Restriction on strike for three years in newly formed establishment and factories with foreign partners shall be removed to enhance the rights of the workers according to the ILO convention 87.

- The provision of selecting trade union leaders under the Labor Act shall be amended in order to ensure the freedom of workers to choose their own leaders from outsiders.

- The Labor Act shall be amended to avoid exploitation of temporary workers by inserting righteous provisions of employment for them.

- Due process must be introduced for termination of workers especially in case of dismissal for misconduct and the alleged worker shall be given the right of being heard in a fair way.

- Ambiguous provision such as fixation of overtime wages for piece-rate laborers shall be specified in the Labor Act.

- The BEPZA laws and instructions shall be revised to standardize the rights and protections of the EPZ workers with the equal footing of the other workers to be fully compliant with the ILO conventions.

- The Labor Act shall be revised with strict penalties against the employers for unfair labor practice such as child labor employment, forced labor and not ensuring workplace safety. 
- Provisions like maternity benefit, payment of compensation and right to call for a strike shall be upgraded to make the Labor Act in more compliance with the core international labor standards.

- Labor education initiatives like training programs, seminars and workshops shall be periodically arranged to aware the workers about their integral rights within the employment.

- Strict and substantive monitoring of the compliance with core international labor standards in both formal and informal labor sectors shall have to be ensured by proper inspection of the Department of Inspection for Factories and Establishments.

- Lastly, the government shall take adequate initiatives to create strong industrial relationship to ensure peace and profitability in the labor sector of Bangladesh free from inhuman clash between employers and workers.

\section{Concluding Remarks}

The core international labor standards and Islamic principles of labor rights are seemed to be addressed by the labor jurisprudence of Bangladesh and labor standards such as boycotting child labor, safeguard against forced labor, ensuring equality and freedom of trade association etc. that have been translated into national labor laws and policies. However, from numerous instances of labor exploitation it is clear that due to lack of effectiveness and certain loopholes of the existing labor laws the labor rights are not satisfactorily ensured in entire labor sector of the country. Apart from the seven ILO conventions Bangladesh has not yet ratified other significant ILO conventions of modern labor standards (Sharma, 2015). Many of the establishment owners are uneager to follow the labor standards outlined by the national labor laws and the Ministry of Labor has also failed to create labor-friendly employment rules to facilitate the core international labor standards. The implementation of the ILO standards and Islamic principles is consistently failing due to poorly balanced industrial relationship between the laborers and employers. Some labor standards are widely promoted while others are left unrecognized in terms of availability as well as effectiveness. Thus the labor regulations in Bangladesh are not efficacious because of existing defects, problematic mechanisms, bureaucratic procedures and lengthy remedial process. The non-compliance of the Bangladesh Labor Act with the core international labor standards and Islamic norms will stir up the sufferings of laborers, industrial costs of employers and interrupt economic prosperity of Bangladesh. The government still needs to make various reforms in labor regulations to put satisfactory compliance with the ILO standards and Islamic labor principles. Numerous pragmatic measures like workplace safety, fair labor practice and good governance shall be practiced to bring tranquility in labor sector of Bangladesh. The legislature shall review and amend the deteriorative provisions of the prevailing labor laws under the spirit of the core international labor standards of the ILO and Islam which can put an end to the untold sufferings of the laborers of every sector in Bangladesh. 


\section{Conflicts of Interest}

The author declares no conflicts of interest regarding the publication of this paper.

\section{References}

Ahmed, P., \& Parvin, R. (2015). Protection of Workers in Workplaces: A Comparative Study of Labour laws of the UK, the USA and Bangladesh. Green University Review of Social Sciences, 2, 93-125.

Aktar, S., \& Abdullah, A. S. M. (2013). Protecting Child Labour in Bangladesh: Domestic Laws versus International Instruments. Bangladesh e-Journal of Sociology, 10, 153-172.

Arshadul, H. K. (2018). Rights of Labourers in Islam: Bangladesh Perspective. Beijing Law Review, 9, 345-356. https://doi.org/10.4236/blr.2018.92022

Chowdhury, M. S. (2017). Compliance with Core International Labor Standards in National Jurisdiction: Evidence from Bangladesh. Labor Law Journal, 68, 78-93.

Chowdhury, T. M., \& Rahel, M. (2018). The Legal Aspect of Industrial Relations Practice in Bangladesh. UUM Journal of Legal Studies, 9, 205-220.

Dhar, N. (2011). Bangladesh Labor \& Industrial Law (Bengali) (3rd ed.). Dhaka: Remisi Publishers.

Elbert, F. C., \& Oelz, M. (2012). Bridging the Gap between Labour Rights and Human Rights: The Role of ILO Law in Regional Human Rights Courts. Geneva: International Institute for Labour Studies.

Halim, M. A. (2019). Text Book on Bangladesh Labour Code (11th ed.). Dhaka: CCB Foundation.

Hossain, J. (2013). Standards-Rights Nexus in Action in Bangladesh: Transforming Labour Standards into Workers' Rights (pp. 1-23). http://www.upf.edu/documents/3298481/3410076/2013-LLRNConf_Hossain.pdf

Hossain, J., Ahmed, M., \& Akter, A. (2010). Bangladesh Labor Law: Reforms Directions (pp. 1-22). Dhaka: Bangladesh Institute of Labor Studies.

Hossain, M. B. (2015). Summary of Bangladesh Labour Code 2006. Dhaka: Galib \& Raisul Legal Solutions.

Islam, M. S., \& Rahman, M. M. (2015). Promoting Bangladesh Labor Law to Managing Human Resources in Enterprises-Perspectives \& Challenges. International Journal of Advances in Management and Economics, 4, 114-123.

Islam, M. Z. (2015). Maternity Benefits in Bangladesh Labor Law: An Empirical Study on Apparel Industry. Manarat International University Studies, 4, 1-11.

Mantouvalou, V. (2012). Are Labour Rights Human Rights? European Labour Law Journal, 3, 151-172. https://doi.org/10.1177/201395251200300204

Paul, N. C. (2014). The Bangladesh Labour Code, 2006 (8th ed.). Dhaka: Shams Publication.

Rubya, T. (2015). The Ready-Made Garment Industry: An Analysis of Bangladesh's Labor Law Provisions after the Savar Tragedy. Brooklyn Journal of International Law, 40, 685-718.

Sarker, S. A., \& Suvo, J. M. (2018). Implementation of Labor Laws for Welfare of Workers: A Study on Ready-Made Garment Factories in Gazipur. Journal of Business Studies, 34, 171-192.

Sharma, V. (2015). Imperfect Work Condition in Bangladesh RMG Sector. International 
Journal of Law and Management, 57, 28-37.

https://doi.org/10.1108/IJLMA-07-2013-0034

Thakur, S. J. (2017). Compensation for Work Related Injury or Illness under the Bangladesh Labour Act. IOSR Journal of Business and Management, 19, 21-26.

Vogt, J. S. (2017). The Bangladesh Sustainability Compact: An Effective Tool for Promoting Workers' Rights? Politics and Governance, 5, 80-92.

https://doi.org/10.17645/pag.v5i4.1093

Zulfiqar, A. A. Z. (2007). Religious Sanctification of Labor Law: Islamic Labor Principles and Model Provisions. University of Pennsylvania Journal of Labor and Employment Law, 9, 421-444. 